\section{THE RELATION BETWEEN GENDER IN THE ACCESS TO DENTAL SERVICES AND GOODS}

\author{
Relação entre o gênero no acesso ao serviço odontológico $e$ \\ aos artigos de higiene bucal
}
La relación del género en el acceso al servicio odontológico y los artículos de higiene bucal

\begin{abstract}
Objective: Identify the influence of gender in the access to dental services and goods such as consultation, toothbrush, toothpaste and dental prostheses use. Methods: Cross-sectional, quantitative and population coverage study, with the population of Guaiuba municipality. Data were collected by Community Health Agents from 2007 to 2008. We used the Community Oral Health Indicator to verify the access to oral health services, oral hygiene, dental visit, use and need of dental prosthesis. Data were analyzed using SPSS 15.0 software, using the chi-square test and significance level of 5\%. Results: 2581 people participated, with a mean age of 24.42 years $(\mathrm{SD} \pm 19,365)$, predominance of females $(\mathrm{n}=1628 ; 63.1 \%)$. Among the interviewees, 2,341 (90.7\%) had access to a toothbrush, $2272(88.0 \%)$ to toothpaste, and $1175(45.5 \%)$ to a dental appointment. The need for dental prosthesis was higher in women, $581(35.7 \%)$ versus $221(23.2 \%)$ men and their access [354 (60.9\%)] versus [96 (43.4\%)] with $\mathrm{p}<0.05$. Conclusion: The access to health services and dental treatment presents gender as an influence factor. Women have most of the needs and benefits.
\end{abstract}

Descriptors: Epidemiology; Oral Health; Health systems.

\section{RESUMO}

Objetivo: Identificar a influência do gênero no acesso ao serviço odontológico e aos artigos de higiene bucal. Métodos: Estudo transversal do tipo quantitativo, tendo como universo a população do Município de Guaiuba-Ceará e coleta de dados realizada por Agentes Comunitários de Saúde treinados, entre 2007 a 2008. Utilizaram-se variáveis do Indicador Comunitário em Saúde Bucal para averiguar acesso aos serviços de saúde, itens de higiene bucal, consulta odontológica, assim como uso e necessidade de prótese dentária. Os dados foram analisados com teste Qui-quadrado de Pearson com nível de significância de 5\%. Resultados: Participaram 2.581 indivíduos, com idade média de 24,4 anos $(D P \pm 19,7)$. Predominou sexo feminino $(63,1 \% ; n=1628)$. Dos entrevistados, 2.341 (90,7\%) tiveram acesso à escova dental, 2.272 (88,0\%) ao dentifrício, 1.175 (45,5\%) à consulta odontológica. A necessidade de prótese dentária foi maior nas mulheres com 581 $(35,7 \%)$ versus $221(23,2 \%)$ homens e seu acesso [354(60,9\%)] versus [96 (43,4\%)] com $p<0,05$. Conclusão: $O$ acesso a artigos de higiene bucal e serviços de saúde e a oferta para tratamento odontológico, apresenta o sexo como fator influenciador. As mulheres possuem a maioria das necessidades e dos beneficios.

Descritores: Epidemiologia; Saúde bucal; Sistemas de Saúde.

\section{Original Article}

Maria Vieira de Lima Saintrain ${ }^{(1)}$ Paulo Leonardo Ponte Marques ${ }^{(1)}$ Lúcio Hélio Pereira de Almeida ${ }^{(1)}$ Caroline Barbosa Lourenço ${ }^{(1)}$ Raimunda Magalhães da Silva ${ }^{(1)}$ Anya Pimentel Gomes Fernandes Vieira $^{(2)}$
Recebido em: $14 / 05 / 2013$ Revisado em: 20/08/2013 Aceito em: 24/04/2014 


\section{RESUMEN}

Objetivo: Identificar la influencia del género en el acceso al servicio odontológico y los artículos de higiene bucal. Métodos: Estudio transversal de abordaje cuantitativo con la población del Município de Guaiuba-Ceará y recogida de datos realizada por Agentes Comunitarios de Salud entrenados, entre 2007 y 2008. Se utilizaron variables del Indicador Comunitario en Salud Bucal para verificar el acceso a los servicios de salud, items de higiene bucal, consulta odontológica bien como el uso y necesidad de prótesis dental. Los datos fueron analizados con la prueba de Chi-cuadrado de Pearson con nivel de significación del 5\%. Resultados: Participaron 2.581 individuos con edad media de 24,4 años $(S D \pm 19,7)$. Hubo predominio del sexo femenino $(63,1 \% ; n=1628)$. De los entrevistados 2.341 (90,7\%) tuvieron acceso al cepillo de dientes, 2.272 (88,0\%) al dentifrico, 1.175 $(45,5 \%)$ a la consulta odontológica. La necesidad de prótesis dental fue mayor en las mujeres con 581 (35,7\%) versus 221 $(23,2 \%)$ hombres y su acceso [354(60,9\%)] versus [96 $(43,4 \%)]$ con $p<0,05$. Conclusión: El acceso a artículos de higiene bucal y servicios de salud y la oferta de tratamiento odontológico presenta el sexo como factor influyente. Las mujeres poseen la mayoría de las necesidades y beneficios.

Descriptores: Epidemiología; Salud bucal; Sistemas de Salud.

\section{INTRODUCTION}

The word 'gender' is used to define those characteristics of women and men that are socially constructed ${ }^{(1)}$, and not always related to sex (masculine and feminine). Men and women frequently think and behave differently. It is widely known that there are differences between men and women in the incidence and prevalence of most health conditions. Sometimes there are clear biological reasons for these differences - but often there are not ${ }^{(2)}$. Gender equality is the absence of discrimination on the basis of a person's sex in opportunities, in the allocation of resources and benefits or in access to services ${ }^{(3)}$. Universal access is a concept that includes, but goes beyond universal coverage. Among the many challenges to ensuring universal coverage, as well as access to health care, are structural inequalities by race, ethnicity and gender ${ }^{(4)}$. Brazilian study has pointed out that there are differences between men and women in the utilization rate of preventive and curative care, as well in hospitalization ${ }^{(5)}$. However, there is a lack of studies investigating the influence of gender regarding access to oral health services in the country.

Constitutionally, Brazil, through the Unified Health System (SUS), guarantees universal access to health services, enabling its use for all individuals, regardless of socio, economic, cultural conditions and gender ${ }^{(()}$.
However, in real life, this universal access is not always achieved, making relevant studies that evaluate access to health care, including oral health care, and the way gender may influence this access.

Despite global advances in health and oral health systems, the importance of achieving a reduction of inequality in access to effective preventive service and dental treatment stands out in several coutries, including United Kingdom, Canada and Brazil. In the United Kingdom, the Primary Care Trust was implemented aiming a change on the approached traditional given to oral health care (e.g., treating people when they've already developed oral health problems) to a more preventive approach ${ }^{(7)}$. In Canada, in order to identify problems, provide measurable goals and help its people to improve and/or maintain oral health through programs and strategies related to access to care and barriers reduction, the Canadian oral health Strategy (COHS) was created $^{(8)}$. In Brazil, the primary health care system was restructured based on the Family Health Strategy (FHS), which focus on the family as the base of care. The National Primary Care Policy ${ }^{(9)}$ and the National Oral Health Policy (Brasil Sorridente - Smiling Brazil $)^{(10)}$ allowed the expansion of oral health care, through the creation of new spaces for oral health practice in the public system. The Family Health Team (FHT) is composed of a doctor, a nurse, a dentist, dental and nurse technical assistants as well as several community health agents (CHA). CHA is a person from the community trained in the health care area. It is responsible for monitoring health issues in the community, as well as for the link between the community and the Health Care Unit ${ }^{(9)}$.

The Smiling Brazil program recommends oral health promotion integrated into the development of public policies that enable strategies for improving access to water and fluoride toothpaste, as well as dental services at health units, especially in basic health care ${ }^{(10)}$. Therefore, decisions have been designated, although efforts are needed to develop a comprehensive policy capable of reducing social inequality in access, in care process and in assessment of epidemiological results in oral health ${ }^{(11)}$.

Andersen and Davidson's model mentioned that access may be influenced by individual factors, the characteristics of the health system itself, the social context and the individual's past experience with the services ${ }^{(12)}$. The authors define as "potential access" the one by which health services, through resources, enables the increase of the likelihood that it will take place and "performed access" as the real use of services, which vary due to various problems such as the perception and needs of users, as well as their social and physical determinants. Women, for example, have special oral health needs and considerations. Hormonal fluctuations have a surprisingly strong influence 
on the oral cavity. Puberty, menses, pregnancy, menopause and use of contraceptive medications all influence women's oral health and the way in which a dentist should approach treatment ${ }^{(13)}$. Furthermore, the use of a service will also depend on the perception of user's needs, influenced by their values, beliefs and cultures ${ }^{(14)}$. As an example, we can mention other study ${ }^{(15)}$ in Istanbul, where more than half of the population surveyed did not feel the need or desire to visit a dentist, although their dental conditions were not ideal.

Concerning access to oral health in Brazil, was pointed $^{(16)}$ that a significant portion of the population does not use dental services frequently, although they acknowledge its importance. This fact has been demonstrated by data from the National Oral Health Survey, entitled SB Brasil, in 2003 and 2010 respectively, in which $15.9 \%$ and $14.7 \%$ of Brazilians had never been to a dentist $\mathrm{t}^{(17,18)}$.

In this perspective, it is important to understand the way access occurs and how it may be influenced by different factors. Therefore, this research aimed to identify the influence of gender in the access to dental services and goods such as consultation, toothbrush, toothpaste and dental prostheses use.

\section{METHODS}

This is a quantitative, cross-sectional study. This study focused on the variables related to: access to oral hygiene goods, utilization of oral health services and use and need of dental prostheses, where the need was based on the absence of prosthesis on those with missing teeth. The survey was conducted from July 2007 to February 2008, using the Oral Health Community Indicator - $\mathrm{OHCI}^{(19)}$, developed to be used by the CHA, in Guaiúba, Ceará, Brazil. Through the OHCI the CHA examined variables related to oral hygiene and utilization to oral health services; use and need for dental prosthesis.

For data collection, 27 CHA were trained in a 40hour workshop to use the OHCI. All eight dentists of the Municipality participated in the workshop in order to follow, monitor and calibrate the CHA. Sixty people from the community were examined for the calibration, which presented good level of concordance with the gold standard - kappa values between 0.74 to $0.90^{(19)}$.

The research was conducted with the population of the municipality of Guaiúba, which was chosen due to some of its characteristics, such as: a. socioeconomic status and urban-rural division similar to the vast majority of the Brazilian municipalities; b. 100\% coverage of primary health care and Family Health Strategy, not found in the majority of Brazilian cities; c. relative small size, which enables the research to be done in the whole city, allowing the comprehension of singularities.

Guaiuba is $26.1 \mathrm{~km}$ far from Fortaleza, capital of Ceará, located in Northeastern Brazil. The city has an area of $267 \mathrm{~km}^{2}$ and 23,502 inhabitants of whom $78.51 \%$ live in the urban area and $21.49 \%$ in the rural area ${ }^{(20)}$. It features $100 \%$ coverage by the FHS, with eight oral health teams distributed in the headquarters and in the municipal districts. The assessment was performed throughout all its area, rural and urban. Random sampling strategy was utilized, setting up households as sampling unit.

It was adopted a sampling error of $1 \%$ with a $95 \%$ confidence interval and a type II error of $8 \%$ obtaining a sample size of 2,524 individuals. In order to achieve this number, it was determined that the CHA should systematically assess one family in every ten houses in their coverage areas, evaluating no more than 5 persons per home. When the house was close, or its residents decline participation, the next-door house was evaluated, if it also decline participation, the previous house was evaluated, and so on, until a willing family was reached. However, the CHA assessed few more houses than necessary, which caused the sample size to exceed, considering the total of 2,581, which reduced the sampling error.

The statistical program SPSS, version 15.0 for Windows (SPSS Inc, Chicago, IL, USA), was used to organize and analyze data. The bivariate analyzes were studied in contingency table through the chi-square test with a significance level of 5\%. Without any conflicts of interest, the study design was approved by the Research Ethics Committee - COÉTICA, University of Fortaleza, No. 001/2007.

\section{RESULTS}

The age of the studied population ranged from one to 99 years (mean 24.4 years, $\mathrm{SD} \pm 19.4$ ), with a predominance of females $(n=1628 ; 63.1 \%)$, and it represented $9.1 \%$ of the city population (estimated in 28,363 inhabitants at the time of the research). There was a difference in the mean age among men and women, where women were, in average, older than men, respectively $26.1( \pm 18.9)$ and $21.5( \pm 19.8)$ years of age.

Among the interviewees, 2341 (90.7\%) had access to a toothbrush, $2272(88.0 \%)$ to toothpaste and $1175(45.5 \%)$ to dental consultation. From the 802 who needed dental prosthesis only $450(56.1 \%)$ had access to them. The data organized by gender can be seen in the table I.

The table I also shows the distribution of the variables concerning the access and statistical significance between male and female interviewees. 
Table I - Distribution of access to toothbrush, toothpaste and dental prostheses, according to the variable, gender. GuaiubaCE, 2008.

\begin{tabular}{|c|c|c|c|c|c|c|c|}
\hline \multirow[b]{2}{*}{ Access } & \multicolumn{2}{|c|}{ Female } & \multicolumn{2}{|c|}{ Male } & \multicolumn{2}{|c|}{ Total } & \multirow[t]{2}{*}{$\mathbf{p}$} \\
\hline & $\mathbf{n}$ & $\%$ & $\mathbf{n}$ & $\%$ & $\mathbf{n}$ & $\%$ & \\
\hline \multicolumn{8}{|l|}{ Toothbrush } \\
\hline Yes & 1497 & 58.0 & 844 & 32.7 & 2341 & 90.7 & $0.004 *$ \\
\hline No & 131 & 5.1 & 109 & 4.2 & 240 & 9.3 & \\
\hline Total & 1628 & 63.1 & 953 & 36.9 & 2581 & 100.0 & \\
\hline \multicolumn{8}{|l|}{ Toothpaste } \\
\hline Yes & 1466 & 56.8 & 806 & 31.2 & 2272 & 88.0 & $0.0001^{*}$ \\
\hline No & 162 & 63.1 & 147 & 5.7 & 309 & 12.0 & \\
\hline Total & 1628 & 6.3 & 953 & 36.9 & 2581 & 100.0 & \\
\hline \multicolumn{8}{|l|}{ Dental Consultation } \\
\hline Yes & 795 & 30.8 & 380 & 14.7 & 1175 & 45.5 & $0.0001^{*}$ \\
\hline No & 833 & 32.3 & 573 & 22.2 & 1406 & 54.5 & \\
\hline Total & 1628 & 63.1 & 953 & 36.9 & 2581 & 100.0 & \\
\hline \multicolumn{8}{|l|}{ If so (Reason) } \\
\hline Emergency & 229 & 19.5 & 117 & 10.0 & 346 & 29.4 & 0.485 \\
\hline Regular consultation & 566 & 48.2 & 263 & 22.4 & 829 & 70.6 & \\
\hline Total & 795 & 67.7 & 380 & 32.3 & 1175 & 100.0 & \\
\hline \multicolumn{8}{|l|}{ Need for prosthesis } \\
\hline Yes & 581 & 22.5 & 221 & 8.6 & 802 & 31.1 & $0.0001^{*}$ \\
\hline No & 1047 & 40.6 & 732 & 28.4 & 1779 & 68.9 & \\
\hline Total & 1628 & 63.1 & 953 & 37.0 & 2581 & 100.0 & \\
\hline \multicolumn{8}{|l|}{ Access to prosthesis } \\
\hline Yes & 354 & 44.1 & 96 & 12.0 & 450 & 56.1 & $0.010^{*}$ \\
\hline No & 227 & 28.3 & 125 & 15.6 & 352 & 43.9 & \\
\hline Total & 581 & 72.4 & 221 & 27.6 & 802 & 100.0 & \\
\hline
\end{tabular}

${ }^{*} \mathrm{p}<0,05$

It is important to note that while $48.8 \%(\mathrm{n}=795)$ of the female interviewed had access to dental consultation in the last year, for male, this percentage was of $39.9 \%(n=380)$. Interestingly, the reason for this consultation, which occurred for 1175 individuals, was not different among those two groups (table), where about $70 \%$ of the cases the reason was a regular consultation and in $30 \%$ of the cases an emergency treatment.

Women had more access to goods and services $(p<0.05)$, as it is shown in the table. Of the 802 interviewees who needed dental prosthesis, women were the ones who showed a greater need, where, from the 1628 interviewed, $35.7 \%(\mathrm{n}=581)$ needed prosthesis versus $23.2 \%(\mathrm{n}=221)$ of men. The access to dental prosthesis was also greater among women, where $21.7 \%(n=354)$ of them had access to prosthesis versus $10.1 \%(n=96)$ of men $(\mathrm{p}<0.05)$. A relationship was found between the need of total dental prosthesis (superior and inferior) and the existence of the dental consultation in the last year $(p<0.001)$, where those who did not had a dental consultation in the last year presented a higher need of total prosthesis. However, this relationship was not observed when analyzing partial dental prosthesis and consultation in the previous year $(\mathrm{p}>0.05)$.

\section{DISCUSSION}

This current research provides advances to enhance understanding on access to dental services and products mainly due to its methodological design. It was a residencebased research and was performed in a whole municipality, being data collected by community health agents. The $\mathrm{CHA}$ is a health agent that is constantly visiting families 
in the community to monitor health issues. Therefore, it has a link with the community, which aids in the reliability of the answers given by the interviewed. All of those characteristics allow a better understanding of the reality, and provide empirical evidence to support formulation of policies regarding access and gender disparities.

The access to dental care, characterized as a dental consultation in the last year, was held for less than half of the interviewees. The dental consultation comprehends the user's entrance in the health service, i.e., it is related to the services offered to the population, prevailing the idea that access is a dimension of the performance of health systems associated to its offer ${ }^{(21)}$.

It is important to mention that the percentage of $45.5 \%$ of access to dental care in this present study does not guarantee access to oral health care to half of the population. At first sight, one can believe that these rates are acceptable and similar to what has been detected in a developed country. However, the understanding of dental access varies from study to study. In the other research ${ }^{(22)}$, which presented a rate of dental access similar to the present study (42.1\%), dental access was perceived as preventive dental care for more than a year for the American population over 18 years of age. Understanding that continuous dental care requests a much deeper relationship with the service than one dental visit per year, it can be inferred that the reality found in the present study still need to be worked in order to provide better access to our population.

The access to the dental care services by the Brazilian population within the age groups 15-19, 35-44 and 65 to 74 years represents an average percentage of $34.4 \%$, while in the Northeast is $28.3 \%$ and in Ceará state $36.9 \%{ }^{(17,23)}$. Maybe this higher accessibility in the state of Ceará is a result of a higher coverage of the family health team in this area, as Ceará state was one of the first one to institutionalize this program in the country ${ }^{(24)}$.

Interestingly, the access to dental service and products are not evenly distributed among gender. In Guaiuba, the data on dental consultation by the population in the last year were higher among women than among men $(p=0.0001)$. In Europe, this uneven gender distribution is also a reality, where women go more to the dentist in a 12 month period than men - Male 54\% x Female 59\%(25). These results are supported by researches that revealed that the number of women who seek the access to dental care is superior to the number of $\operatorname{men}^{(16)}$.

The predominance of females in this research points to an apparent feminization of health access, which may be due to several factors, including the fact that women commonly act as a family caregiver, as well as due to more specialized services offered for this group. Prenatal care, birth control planning programs, escort children and old age family members to consultations in the health care unit, bring the women more often to the unit and, therefore, to have access to its services as well as to be more sensitive to health care and its products.

Men are generally responsible for the family income and work at the same time as health facilities are functioning, thus hindering the search for treatment ${ }^{(6)}$. Looking deeper in the gender disparity related to health access, was emphasized that men, for feeling invulnerable, expose themselves and end up getting more vulnerable ${ }^{(26)}$. They also find possible explanations for the lower demand for health care services by men in the adoption of self-care practices, as well as in facts related to the cultural moorings of manhood (man seen as virile, strong and invulnerable), in the fear of discovering serious diseases, in the shame of body exposure, in the lack of available time to search treatment and in the lack of health units specific for their health problems ${ }^{(26)}$.

Among the people who need prosthesis in this current study, the percentage of women $(35.7 \%)$ is much higher than men $(23.2 \%)$, however, access to dental prosthesis is also higher among women $(60.9 \%$ vs $43.4 \%)$. The explanation for this finding is not easy, but it may be related to the age difference found in the present study (where women are older than men and therefore may have higher dental necessities). Nevertheless, other authors have already found that, in Brazil, "paradoxically, dental lost is higher on those individuals that go to dentist more frequently"(27). In this context, further studies are recommended. The detection of differences regarding the use and need of dental prosthesis among men and women assume cultural, familiar, financial, educational aspect, that have not been the focus of the present study, but which deserve further investigation.

Commonly, the dental services are linked to oral health rehabilitation (dental treatment), and not related to oral health promotion and prevention activities. There are criticizes this framework of dental practice, based on biological and individual aspects, which ignores the complexity of social processes involved in oral health ${ }^{(28)}$. If one consider that dental services aims the treatment of a disease already installed, then the access to oral health services per se it's proven not to be able to improve the health conditions of a population ${ }^{(28)}$. On the other hand, if the dental service aims not only the treatment of the disease, but also to promote oral health, then, the expected outcome will be different. In New Zeeland, for example, patients with a routine access to services have a better self-reported oral health condition, less tooth decays and a lower rate of tooth $\operatorname{loss}^{(29)}$. This study supports the notion that routine dental care is associated with better oral health outcomes which are suitable for oral health education in order to make people 
aware of the importance of regular dental consultations since they are regarded as pillars of preventive dentistry ${ }^{(30)}$.

In Brazil, the family health team should performed actions related to oral health promotion, prevention and rehabilitation, therefore, the end result of a better access to dental services should be linked to higher levels of oral health for the population. However, in order to obtain good oral health, health supplies and products are necessary. Interestingly, the distribution of those goods among the population seems to be, once again, gender-related.

The use of toothbrush and toothpaste, for example, is made by most of the participants $(90.7 \%$ and $88 \%$ respectively) in this research. However, the analysis by gender revealed that women had more access to this mechanical device used for oral hygiene $(\mathrm{p}=0.004)$ - $92 \%$ female versus $88.6 \%$ male regarding toothbrush. The same was detected regarding toothpaste, which the difference between genders was also significant $(\mathrm{p}=0.0001)$, where $90 \%$ female had access to toothpaste versus $84.6 \%$ of males.

Once again, the explanation may be related to the facts pointed out by other research ${ }^{(26)}$, that find regarding access to health services. However, the fact that women participate more in health service may also influence this higher percentage of women utilizing health products. As they have more access to health services, women also tend to have more access to health education programs developed by those units, which may influence their empowerment regarding oral hygiene care, thus influencing the use of oral health products.

It was noted in this current study that the percentage of people who have toothbrush is slightly higher than the ones who have toothpaste. Although the study didn't evaluate the attitude in the use of the toothbrush, this difference is probably due to the fact that the brush costs less than the toothpaste regarding the time of use.

The consumption of toothpaste is significantly higher in families with a higher income ${ }^{(31)}$. Within this context, we must consider that the National Oral Health Policy Smiling Brazil - was responsible for delivering thousands of kits with toothpaste and toothbrush in all municipalities that are covered by family health teams ${ }^{(32)}$, which, once more, reinforce the idea that access to dental services is linked with higher use of oral products, as the dental products were mainly distributed in schools and at the health unit.

A percentage of $56.14 \%$ of the interviewed for this current study need some type of dental prosthesis, i.e., they are total or partially edentulous. Calling out to this problem, was explained that the use of dental prosthesis will be responsible not only for chewing function and nutritional intake, but also a physical and social improvement in quality of life ${ }^{(33)}$. It is known that there is a great number suppressed demand regarding dental extraction and dental prosthesis in the Brazilian public health system. Thus, priority access to dental prostheses services (while the suppressed demand problem is not solved) becomes a matter of great importance, leading managers to seek strategies to formulate public policies on this matter ${ }^{(14)}$. On the other hand, the addressing of oral health problems should also occur from a joint partnership between society and the public sector ${ }^{(34)}$. This articulation makes it easier to meet the need for oral health found and to direct the actions in order to reduce inequalities, which sometimes are clearly evident in the oral health status of the Brazilian population.

\section{CONCLUSION}

The access to health services and dental treatment presents gender as an influence factor. Women have most of the needs and benefits. The edentulism affects mostly the population with a poor access to dental prosthesis.

\section{REFERENCES}

1. World Health Organization - WHO. Mainstreaming gender equity in health: the need to move forward (the Madrid Statement). Geneva: WHO; 2004.

2. Wilkins D, Payne S, Granville G, Branney P. The gender and access to health services study - final report [Internet]. Bristol: Department of health, Men`s Health Forum/ University of Bristol; 2008. [cited 2012 Oct 29]. Available from: http://www.dh.gov.uk/ prod_consum_dh/groups/dh_digitalassets/@dh/@en/ documents/digitalasset/dh_092041.pdf

3. World Health Organization - WHO. Gender toolEuropean strategy for child and adolescent health and development [Internet]. WHO/Regional Office for Europe; 2007. [cited 2012 Oct 29]. Available from: http://www.euro.who.int/ data/assets/pdf file/0020/76511/EuroStrat_Gender_tool.pdf

4. Ravidran TK. Universal access: making health systems work for women. BMC Public Health [Internet]. 2012 [cited 2013 Nov 18];12(Suppl 1):S4. Available from: http://www.biomedcentral.com/1471-2458/12/S1/S4.

5. Pinheiro RS, Viacava F, Travassos C, Brito AS. Gênero, morbidade, acesso e utilização de serviços de saúde no Brasil. Ciênc Saúde Coletiva. 2002;7(4):687-707.

6. Silva KC, Sousa AS, Carnut L, Rodrigues CS. Percepção sobre o acesso aos serviços de atenção primária à saúde bucal: uma perspectiva de gênero. J Manag Prim Health Care. 2010;1(1):1-7. 
7. Department of Health Choosing Better Oral Health (UK). An Oral Health Plan for England. Department of Health: Dental and Ophthalmic [Internet]. 2005 [cited 2012 Oct 13]. Available from: http:// www.berkshirewest.nhs.uk/_store/documents/ choosingbetteroralhealth.pdf

8. Chairman MW, Maze BA. Canadian Oral Health Strategy [Internet]. [cited 2012 Feb 21] Available from: http://www.fptdwg.ca/assets/PDF/Canadian $\% 20$ Oral\%20Health\%20Strategy\%20-\%20Final.pdf

9. Ministério da Saúde (BR). Portaria $n^{0} 2.488$, de 21 de outubro de 2011. Aprova a Política Nacional de Atenção Básica, estabelecendo a revisão de diretrizes e normas para a organização da Atenção Básica, para a Estratégia Saúde da Família (ESF) e o Programa de Agentes Comunitários de Saúde (PACS). Diário Oficial da República Federativa do Brasil, Brasília; 2011.

10. Ministério da Saúde (BR). Diretrizes da Política Nacional de Saúde Bucal [Internet]. Brasília; 2004. [cited 2012 Feb 16]. Available from: http://dab.saude. gov.br/CNSB/brasil_sorridente.php

11. Chagas RA, Nuto SAS, Andrade LOM. Política municipal de saúde bucal: da construção coletiva ao desafio de seu desenvolvimento em Fortaleza (CE). Divulg Saúde Debate. 2008;(42):35-50.

12. Baldani MH, Antunes JLF. Inequalities in access and utilization of dental services: a cross-sectional study in an area covered by the Family Health Strategy. Cad Saúde Pública. 2011;27(Supl 2):272-83.

13. American Dental Association. Women's Oral Health Issues [Internet]. 2011. [cited 2012 Dez 2]. Available from: http://www.iom.edu/ /media/Files/Activity $\% 20$ Files/Women/PreventiveServicesWomen/Patton.pdf

14. Giordani JMA, Slavutzky SMB, Koltermann AP, Pattussi MP. Inequalities in prosthetic rehabilitation among elderly people: the importance of context. Community Community Dent Oral Epidemiol. 2010;39(3):230-8.

15. Ozkan Y, Özcan M, Kulak Y, Kazazoglu E, Arikan A. General health, dental status and perceived dental treatment needs of an elderly population in Istanbul. Gerodontology. 2011;28(1):28-36.

16. Gibilini C, Esmeriz CEC, Volpato LF, Meneghim ZMAP, Silva DD, Sousa MLR. Acesso a serviços odontológicos e auto-percepção da saúde bucal em adolescentes, adultos e idosos. Arq Odontol. 2010;46(4):213-23.
17. Ministério da Saúde (BR). Projeto SB Brasil 2003. Condições de saúde bucal da população brasileira 20022003. Resultados Principais. Brasília: Coordenação Nacional de Saúde Bucal; 2004.

18. Ministério da Saúde (BR). SB Brasil: Pesquisa Nacional de Saúde Bucal 2010 - Resultados principais. Brasília: Coordenação Nacional de Saúde Bucal; 2011.

19. Saintrain MVL, Vieira APGF. Application of the Community Oral Health Indicator by Non-Dental Personnel and Its Contribution to Oral Healthcare. PLoS ONE. 2012;7(7):e39733.

20. Instituto Brasileiro de Geografia e Estatística - IBGE. Sinopse do Censo Demográfico 2010 [Internet]. Brasília: Ministério do Planejamento e Gestão [cited 2011 Oct 06]. Available from: http://www.ibge.gov. br/home/estatistica/populacao/censo2010/default sinopse.shtm

21. Pereira CRS, Patrício AAR, Araújo FAC, Lucena EES, Lima KCL, Roncalli AGR. Impacto da Estratégia Saúde da Família com equipe de saúde bucal sobre a utilização de serviços odontológicos. Cad Saúde Pública. 2009;25(5):985-96.

22. Ahn S, Burdine JN, Smith ML, Ory MG, Phillips CD. Residential Rurality and Oral Health Disparities: Influences of Contextual and Individual Factors. J Primary Prevention. 2011;32(1):29-34.

23. Secretaria da Saúde do Estado do Ceará. Levantamento epidemiológico em Saúde Bucal no Estado do Ceará SB Ceará: Resultados finais. Fortaleza: Secretaria da Saúde do Estado do Ceará; 2004.

24. Albuquerque ABB, Bosi MLM. Visita domiciliar no âmbito da Estratégia Saúde da Família: percepções de usuários no Município de Fortaleza, Ceará, Brasil. Cad Saúde Pública. 2009;25(5):1103-12.

25. Report Oral Health - Special Eurobarometer $330 /$ Wave 72.3 - TNS Opinion \& Social. [Internet]. 2010. [cited 2012 Dez 2]. Available from: http://ec.europa.eu/ public_opinion/archives/ebs/ebs_330_en.pdf

26. Gomes R, Nascimento EF, Araújo FC. Por que os homens buscam menos os serviços de saúde do que as mulheres? As explicações de homens com baixa escolaridade e homens com ensino superior. Cad Saúde Pública. 2007;23(3):565-74.

27. Antunes JLF, Narvai PC. Políticas de saúde bucal no Brasil e seu impacto sobre as desigualdades em saúde. Rev Saúde Pública. 2010;44(2):360-5. 
28. Narvai PC. Saúde bucal coletiva, bucalidade e antropofagia. Ciênc Saúde Coletiva. 2006;11(1):18-21.

29. Thomson WM, Williams SM, Broadbent JM, Poulton R, Locker D. Long-term dental visiting patterns and adult. oral health. J Dent Res. 2010;89(3):307-11.

30. Richards W, Ameen J. The impact of attendance patterns on oral health in a general dental practice. Br Dent J. 2002;193(12):697-702.

31. Colussi PRG, Haas AN, Oppermann RV, Rösing CK. Consumo de dentifrício e fatores associados em um grupo populacional brasileiro. Cad Saúde Pública. 2011; 27(3):546-54.

32. Ministério da Saúde (BR). SB Brasil: Pesquisa Nacional de Saúde Bucal 2010 [Internet]. 2010 [cited 2012 Feb 11]. Available from: http://dab.saude.gov.br/ CNSB/sbbrasil/arquivos/apresentacao_abbrasil_2010. pdf
33. Kuo HC, Yang YH, Lai SK, Yap SF, Ho PS. The Association between health-related quality of life and prosthetic status and prosthetic needs in Taiwanese adults. J Oral Rehabil. 2009;36(3):217-25.

34. Narvai PC, Frazão P. Saúde bucal no Brasil: muito além do céu da boca. Rio de Janeiro: Fiocruz; 2008. 